УДК 355.43

Лепіхов А. В. ${ }^{1}$

$(0000-0003-0745-8113)$

Храпач Г. С. ${ }^{2}$

(0000-0002-1089-1535)

1 - Національний інститут стратегічних досліджень, Київ;

2 - Центр воєнно-стратегічних досліджень Національного університету оборони України імені Івана Черняховського, Київ

\title{
Завдання ключових інститутів стратегічного аналізу при Раді національної безпеки США
}

Резюме У статті досліджено завдання ключових інституційних суб’єктів стратегічного аналізу, які забезпечують цей процес на рівні Ради національної безпеки Сполучених Штатів Америки. Виокремлено позитивний досвід для розбудови інституційної системи державного стратегічного аналізу у сфері національної безпеки України.

Ключові слова: стратегічний аналіз; прогнозування; оцінка; планування; національна безпека; ризики; загрози; система забезпечення.

Постановка проблеми. Відповідно до п. 4.2. Стратегії національної безпеки України від 06.05.2015 [4], стратегічно важливим завданням державної політики України є удосконалення державної системи стратегічного планування, створення єдиної системи моніторингу, аналізу, прогнозування та прийняття рішень у сфері національної безпеки і оборони, забезпечення ефективної координації та функціонування єдиної системи ситуаційних центрів профільних органів державної влади сектору безпеки i оборони. Зазначене актуалізує проблематику наукової статті.

Аналіз останніх досліджень i публікацій. Вказану наукову проблему досліджували вітчизняні науковці: Г. Ситник [5], М. Шевченко [5, 13], В. Смолянюк [5], Р. Марутян [10], Л. Шипілова [10], В. Соколов [8], С. Іванов [3] та інші. Основну увагу приділено дослідженню методологічних підходів до проведення стратегічного аналізу і прогнозування загроз у сфері національної безпеки (НБ). Утім під час дослідження досвіду Сполучених Штатів Америки наукові зусилля, переважно, зведені до загальної характеристики діяльності окремих державних i неурядових інститутів цієї країни, що здійснюють інформаційно-аналітичне забезпечення державної політики США у сфері НБ. Отже, тема статті має свою актуальність.

Метою статті $\epsilon$ дослідження актуального досвіду США щодо розбудови системи стратегічного аналізу у сфері національної безпеки для його використання в інтересах розвитку сектору безпеки і оборони України. Зазначене сприятиме: визначенню оптимальної i найбільш ефективної моделі міжвідомчої діяльності і взаємодії під час проведення стратегічного аналізу у сфері НБ, яка позитивно себе зарекомендувала у провідних іноземних практиках.

Виклад основного матеріалу. У Сполучених Штатах Америки державний стратегічний аналіз у сфері НБ децентралізованим процесом 3 чітким розмежуванням повноважень між його учасниками. Використовується колегіальний підхід до розроблення стратегії протидії безпековим загрозам та державної політики у сфері НБ із залученням міжвідомчих комітетів i експертних груп [1]. Методика стратегічного аналізу полягає у завчасному передбаченні безпекових загроз та виявлені джерел, прогнозуванні розвитку обстановки, попередженні фактів вияву загроз безпеки, завчасному розробленню заходів реагування i планів використання резервів.

у США функціонує Директорат стратегічного планування (Strategic Planning Directorate) при Апараті Ради Національної Безпеки США (АРНБ), який здійснює міжвідомчу координацію та контроль за дотриманням державними органами США принципів забезпечення стратегічного розвитку i безпеки країни. Функцію стратегічного аналізу виконують профільні експертно-аналітичні підрозділи (цільові міжвідомчі робочі групи) при АРНБ у взаємодії 3: міжвідомчими комітетами Ради Національної Безпеки США; Центром відстеження обстановки АРНБ США; Розвідувальним співтовариством США; неурядовими консалтинговими структурами США.

Характеризуючи функції i завдання ключових суб'єктів державного стратегічного аналізу США доцільно зосередити увагу на таких інститутах (рис. 1). 


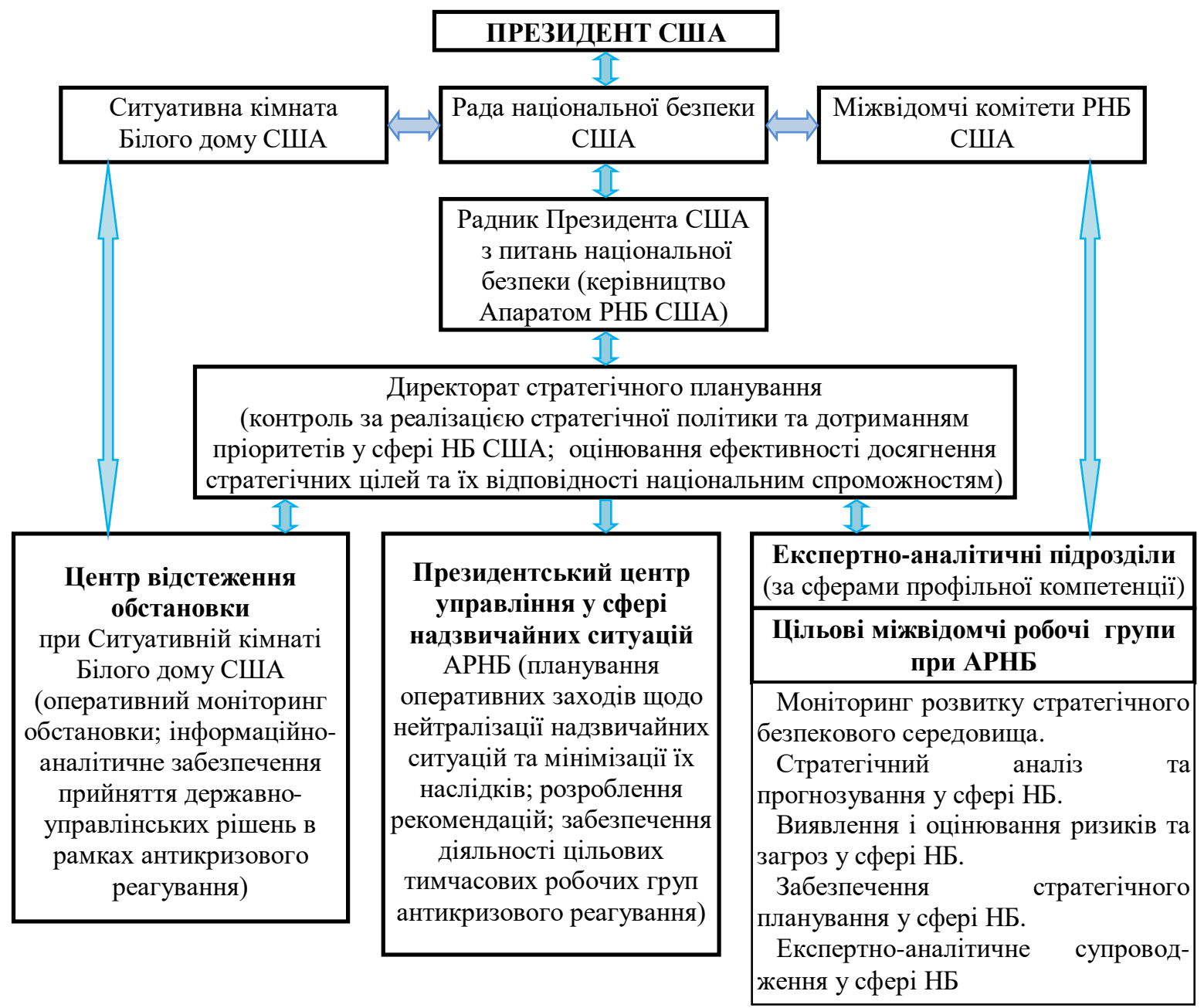

Рис. 1. Схема системи стратегічного аналізу у сфері національної безпеки США

Aпарат Ради начіональної безпеки США

(US National Security Council Staff) [2] $\epsilon$ головним координуючим органом у системі стратегічного аналізу, прогнозу і планування у сфері національної безпеки. Керівництво здійснює Радник Президента США з питань національної безпеки. На нього покладено місію забезпечення діяльності Ради національної безпеки США та вирішення завдань щодо координації загальнодержавного процесу стратегічного аналізу, прогнозу i планування політики національної безпеки США та іï трансформації у цілеспрямовану, скоординовану діяльність органів державної влади і суспільства, зорієнтовану на захист національних цінностей $\mathrm{i}$ інтересів від загроз воєнного і невоєнного характеру.

Апарат виконує функції координаційну, інтеграційну, організаційноуправлінську, аналітично-прогностичну, цілевизначення, цілепокладання, програмнотеоретичну, моніторингу і контролю.

Директорат стратегічного планування при АРНБ США (Strategic Planning Directorate) [2, с.30] - державний орган при АРНБ США, який виконує завдання: координація міжвідомчої стратегічної політики у сфері національної безпеки;

забезпечення підтримки головних пріоритетів Адміністрації Президента США у сфері національної безпеки, передусім, які потребують стратегічних підходів до розроблення директивних вказівок;

забезпечення взаємодії Президента США 3 ключовими стратегічними партнерами на міжнародній арені;

окреслення основних і проміжних цілей та завдань державного стратегічного аналізу i планування у сфері НБ;

узгодження стратегічних цілей 3 реальними ресурсними можливостями держави;

координація діяльність федеральних органів влади у питаннях стратегічного планування;

контроль за узгодженістю i відповідністю стратегічного планування в державі;

моніторинг виконання 3 боку профільних міністерств та відомств настанов стратегії національної безпеки, інших 
програмно-цільових документів у сфері національної безпеки США;

оцінювання ефективності досягнення стратегічних цілей;

формулювання пропозицій щодо внесення коректив у стратегічне планування у сфері національної безпеки або щодо державної політики реагування на виклики та небезпеки;

розроблення для Президента США планових заходів щодо врегулювання непередбачених кризових ситуацій;

допомога Радникові Президента США 3 питань національної безпеки в розробленні і реалізації спеціальних проєктів.

Директорат взаємодіє 3 міжвідомчими комітетами при РНБ та експертноаналітичними підрозділами у складі АРНБ США, Кабінетом Президента США (зокрема, 3 Офісом 3 управління та бюджету), Департаментом фінансів США, профільними радами при Президенті США (зокрема, 3 Радою економічних консультантів, Радою федеральної резервної системи), Об'єднаним комітетом штабів ЗС США (зокрема, 3 управлінням стратегічного планування та довгострокової політики (J-5)), Міністерством оборони США, Міністерством внутрішньої безпеки США, Директором Національної розвідки США.

Експертно-аналітичні підрозділи при АРНБ США $[2,3,7]$ - структурні експертноаналітичні сектори АРНБ, які функціонують на постійній основі 3 метою виконання профільних завдань у сфері національної безпеки. До штату входять висококваліфіковані експерти 3 федеральних міністерств та відомств, науково-дослідних організацій тощо, які залучаються (терміном на 2 роки) до виконання завдань у сфері стратегічного аналізу. Сфери відповідальності розмежовані за регіональним та функціональним принципом реалізації державної політики США. Використовується Інформаційна мережа національної безпеки CША (HSIN). Передбачено створення тимчасових міжвідомчих груп при АРНБ, 3 метою виконання цільових завдань у сфері забезпечення національної безпеки, у тому числі 3 метою розроблення стратегічних програмних документів.

Експертно-аналітичні

підрозділи

виконують завдання:

проведення стратегічного аналізу, прогнозування, ідентифікації та оцінювання загроз національній безпеці; систематизація національних інтересів, розроблення реєстру i формування діаграми загроз та визначення пріоритетів у сфері національної безпеки США;

узагальнення аналітичних звітів щодо розвитку безпекового середовища та загроз на міжнародному i національному рівнях на основі оцінок розвідувального співтовариства, міністерства внутрішньої безпеки, недержавних консалтингових структур та інших суб'єктів забезпечення національної безпеки США;

підготовка рекомендацій щодо визначення мети, основних і проміжних цілей та завдань державного стратегічного планування у сфері НБ, участь у розробленні стратегії і комплексу заходів щодо здійснення політики національної безпеки;

експертно-аналітичне супроводження процесу розроблення стратегічних програмних документів США у взаємодії 3 розвідувальним співтовариством, міністерством внутрішньої безпеки, державним департаментом США тощо; забезпечення діяльності міжвідомчих комітетів Ради національної безпеки США.

Центр відстеження обстановки при Ситуативній кімнаті Білого Дому США $[6,8]$ - оперативний центр моніторингу i ситуативного аналізу при АРНБ, який забезпечує президента США i iнших посадовців розвідувальною і відкритою інформацією для вироблення i реалізації політики у сфері кризового реагування, включаючи природні та техногенні катастрофи, а також інформаційно-аналітичне супроводження діяльності Апарату Ради національної безпеки США щодо координації i контролю за діяльністю суб'єктів забезпечення національної безпеки, зокрема в умовах виникненні кризових ситуацій. Провідним підрозділом є Група оперативних чергових. Взаємодіє з експертними та іншими підрозділами і групами АРНБ, зокрема під час діяльності у сфері стратегічного аналізу, прогнозу і планування.

Центр виконує завдання:

моніторинг ключових тенденцій розвитку міжнародної обстановки; відстеження оперативної обстановки, конкретних кризових ситуацій і подій в країні і за кордоном;

обробка поточної інформації, що надходить 3 державних i недержавних інформаційних баз даних США;

первинне оцінювання рівня ризиків i загроз та оперативне відпрацювання 
першочергових управлінських рішень щодо їх локалізації;

підготовка щоденних експертноаналітичних оглядів та оперативних звітів щодо актуальних подій;

інформаційне забезпечення закордонних візитів керівництва держави.

Президентський иентр управління надзвичайними ситуачіями АРНБ США (President's Emergency Operations Center) [6] допоміжний підрозділ Центру відстеження обстановки 3 питань антикризового реагування, який виконує завдання: моніторинг “кризовової” обстановки; розроблення рекомендацій щодо врегулювання кризових ситуацій; формування, координація та забезпечення діяльності цільових міжвідомчих груп, які врегульовують кризові явища; планування оперативних заходів реагування на кризові ситуації та проведення тренувальних навчань.

$$
\text { Міжвідомчі комітети Ради }
$$

начіональної безпеки США (РНБ) [3] -
державні колегіальні органи при Раді національної безпеки США. Місією комітетів $\epsilon$ міжвідомче узгодження і координація дій 3 питань розроблення державної політики у сфері національної безпеки. Вони функціонують на трьох ієрархічних рівнях розроблення державно-політичних рішень при РНБ США:

1-й - керівники відомств;

2-й - заступники керівників відомств;

3-й - помічники заступників керівників відомств.

Сфери відповідальності розмежовані за регіональним та функціональним принципами реалізації зовнішньої і внутрішньої державної політики США. Взаємодіють з експертними та іншими підрозділами i групами АРНБ, зокрема під час діяльності у сфері стратегічного аналізу і планування.

На Міжвідомчі комітети покладено такі завдання:

аналіз тенденцій розвитку стратегічного безпекового середовища, із залученням експертно-аналітичних сил і засобів профільних відомств;

дослідження цільових проблем національної безпеки, здійснення міжвідомчого погодження та розроблення проєктів стратегічних i державноуправлінських рішень щодо їх розв'язання; погодження обсягів ресурсного забезпечення (фінансових, матеріальних та ін.) на потреби національної безпеки (внутрішньої безпеки); контроль та забезпечення своєчасного виконання профільними міністерствами та відомствами прийнятих стратегічних i управлінських рішень Президентом США;

забезпечення розроблення, розгляду та затвердження стратегічних та державноуправлінських документів у сфері національної безпеки США;

антикризове оперативне управління при РНБ США (рівень заступників відомств).

Результати дослідження свідчать, що досвід США може бути корисним. Його доцільно розглянути у контексті перспективності створення при РНБО України міжвідомчих робочих груп у сфері НБ.

Моделі зазначених робочих груп повинні відтворювати певні особливості $\ddot{1}$ функціонування. Зокрема, робочі групи мають функціонувати на постійній основі для виконання профільних завдань у сфері національної безпеки. Сфери відповідальності доцільно розмежувати за регіональним та функціональним принципом реалізації державної зовнішньої і внутрішньої політики України. Інформаційно-аналітичне i організаційно-технічне забезпечення діяльності міжвідомчих робочих груп мають здійснювати державні органи, представники яких беруть участь у роботі цих груп, а також апарат РНБО України. Штат робочих груп має складатися 3 висококваліфікованих експертів 3 міністерств і відомств, науково-дослідних організацій України тощо. Їх доцільно залучати (терміном на 2 роки) до виконання завдань у сфері стратегічного аналізу. Це забезпечить:

надійний комунікативний зв'язок i обмін інформацією між представниками міжвідомчих робочих груп i галузевими міністерствами, насамперед, на рівні міжособистих стосунків;

залучення фахівців-практиків, які мають відповідну професійну свідомість, володіють розвитком обстановки та спроможні об'єктивно оцінити ризики і загрози в галузі своєї компетентності;

підвищення професійної підготовки відряджених експертів-аналітиків (сформувати стратегічне мислення державницького рівня) під час практичної їх роботи в РНБО;

можливість використання експертамианалітиками отриманого досвіду в РНБО (після їх повернення на попереднє місце служби) в інтересах розвитку сектору безпеки i оборони України. 
Висновки. Досвід США свідчить, що ефективність державного стратегічного аналізу i планування у сфері НБ зростатиме під час застосування державою колегіального принципу виконання цієї функції. Оптимізації процесу сприятиме формуванню міжвідомчих: експертних рад, комітетів, комісій, цільових груп тощо, які братимуть участь у стратегічному аналізі та розробленні стратегічних програмних документів. Крім того, перспективним $\epsilon$ залучення державою у зазначених цілях неурядових консалтингових структур. Це забезпечуватиме конкуренцію думок та їх синтез у єдину концепцію розв'язання проблеми, збалансування інтересів держави i громадянського суспільства, а також сприятиме визначенню пріоритетів і прийняттю виважених стратегічних управлінських рішень.

\section{СПИСОК ВИКОРИСТАНОЇ ЛІТЕРАТУРИ}

1. Elements of national security strategy. Atlantik Consul (28.02.2019) URL: https://www.atlanticcouncil.org/ content-series/strategy-consortium/elements-ofnational-security-strategy. (дата звернення: 02.03.2020).

2. The National Security Policy Process:The National Security Council and Interagency System URL: https://issat.dcaf.ch/download/17619/205945/icaf-nscpolicy-process-report-08-

2011.pdfThe $\% 20$ National $\% 20$ Security $\% 20$ Policy $\% 20 \mathrm{P}$ rocess:\%20The\%20National\%20Security\%20Council\% 20and\%20Interagency\%20System (дата звернення: 02.03.2020).

3. Иванов С. Структура и функции Совета национальной безопасности США (2013) URL: http://pentagonus.ru/publ/struktura_i_funkcii_soveta_na cionalnoj_bezopasnosti_ssha_2013/19-1-0-2407 (дата звернення: 02.03.2020).

4. Про рішення Ради національної безпеки і оборони України від 26.05.2015 р. № 287/2015 "Про Стратегію національної безпеки України". URL: https://zakon.rada.gov.ua/laws/show/287/2015 (дата звернення: 06.03.2020).

5. Ситник Г. П., Смолянюк В. Ф., Шевченко М. М. Геополітичний аналіз та прогнозування : навч. посіб. / за заг. ред. Г. П. Ситника. Київ : НАДУ, 2014. Ч. 1. 180c.

6. Ситуационные центры: За рубежом (20.06.2018) URL: http://www.rosinform.ru/security/72242situatsionnye-tsentry-za-rubezhom/ (дата звернення: 02.03.2020).

7. Совет национальной безопасности США (03.01.2015) URL: http://www.zvo.su/voennyeproblemy/sovet-nacionalnoy-bezopasnosti-ssha.html (дата звернення: 06.03.2020).

8.Соколов В. А. Інституційні засади інформаційноаналітичного забезпечення політики національної безпеки США. Державне управління $і$ національна безпека : зб. матеріалів I міжнар. наук.-практ. конф. (EPRGNS 2016). 2016. С. 99-102.

9. Шевченко М. М. Методи державного реагування на загрози національній безпеці. Енциклопедія державного управління : у 8 т. / наук.-ред. колегія : Ю. В. Ковбасюк (голова) та ін. Київ : НАДУ, 2011. T. 2. C. $312-313$.

10. Шипілова Л. М., Марутян Р. Р. Аналітичні засоби стратегічного планування забезпечення національної безпеки в умовах глобальних загроз національній безпеці та міжнародній стабільності. Збірник наукових праџь Національної академіі державного управління при Президентові України. Київ, 2017. Вип. 2. С. 88-104.

\section{Стаття надійшла до редакційної колегії 03.04.2020}

\section{Tasks of key institutions of strategic analysis at the US National Security Council}

\footnotetext{
Annotation

In accordance with the National Security Strategy of Ukraine, a strategically important task of the state policy of Ukraine is:

To improve the state system of strategic planning;

To creation of a unified system of monitoring, analysis, forecasting and decision-making in the field of national security and defense; ensuring effective coordination and functioning of a unified system of situational centers of relevant public authorities in the security and defense sector.

This actualizes the issues of the scientific article.

The purpose of the article is to research an experience of the United States in developing a system of strategic analysis in the field of National Security for its use in the interests of the development of the Security and Defense sector of Ukraine.

This will contribute to:

Determine the optimal and most effective model of interagency activities and cooperation in conducting strategic analysis in the field of National Security, which has proven itself in leading foreign practices. The scheme of the system of strategic analysis in the field of United States National Security is given.

The United States experience shows that the effectiveness of state strategic analysis and planning in the field of the National Bank will increase when the state applies the collegial principle of performing this function.

The optimization of the process will be facilitated by the formation of interdepartmental: expert councils, committees, commissions, task forces, etc., which will take part in strategic analysis and development of strategic program documents. It is promising for the state to involve non-governmental organizations for these purposes.

This will ensure the competition of opinions and their synthesis into a single concept of solving the problem, balancing the interests of the state and civil society, as well as contribute to the definition of priorities and the adoption of sound strategic management decisions.

Keywords: strategic analysis; forecasting; assessment; planning; National security; risks; threats; support system.
} 